\title{
Comparative study of the explosion pressure characteristics of micro- and nano-sized coal dust and methane-coal dust mixtures in a pipe
}

\author{
Bo $\operatorname{Tan}^{1} \cdot$ Huilin $\mathrm{Liu}^{1} \cdot \operatorname{Bin} \mathrm{Xu}^{1} \cdot \operatorname{Tian}^{\mathrm{Wang}}{ }^{1}$
}

Received: 16 August 2019/Revised: 4 October 2019/Accepted: 8 December 2019/Published online: 3 January 2020

(C) The Author(s) 2020

\begin{abstract}
Coal dust explosion accidents often cause substantial property damage and casualties and frequently involve nano-sized coal dust. In order to study the impact of nano-sized coal on coal dust and methane-coal dust explosions, a pipe test apparatus was used to analyze the explosion pressure characteristics of five types of micro-nano particle dusts (800 nm, $1200 \mathrm{~nm}, 45 \mu \mathrm{m}, 60 \mu \mathrm{m}$, and $75 \mu \mathrm{m})$ at five concentrations $\left(100 \mathrm{~g} / \mathrm{m}^{3}, 250 \mathrm{~g} / \mathrm{m}^{3}, 500 \mathrm{~g} / \mathrm{m}^{3}, 750 \mathrm{~g} / \mathrm{m}^{3}\right.$, and $\left.1000 \mathrm{~g} / \mathrm{m}^{3}\right)$. The explosion pressure characteristics were closely related to the coal dust particle size and concentration. The maximum explosion pressure, maximum rate of pressure rise, and deflagration index for nano-sized coal dust were larger than for its micro-sized counterpart, indicating that a nano-sized coal dust explosion is more dangerous. The highest deflagration index $K_{s t}$ for coal dust was $13.97 \mathrm{MPa} /(\mathrm{m} \cdot \mathrm{s})$, indicating weak explosibility. When $7 \%$ methane was added to the air, the maximum deflagration index $K_{s t}$ for methane-coal dust was $42.62 \mathrm{MPa} /(\mathrm{m} \cdot \mathrm{s})$, indicating very strong explosibility. This indicates that adding methane to the coal dust mixture substantially increased the hazard grade.
\end{abstract}

Keywords A pipe test apparatus · Nano-sized · Coal dust explosion - Methane/coal dust explosion · Pressure characteristics

\section{Introduction}

Coal dust explosions are among the main hazards affecting coal mine safety (Wu et al. 2011). Statistically, $87.32 \%$ of China's 532 key national mines face the risk of coal dust explosions (Zheng et al. 2009). Due to complex coal mine production environments, both methane and coal dust are often involved in coal dust explosions. In recent years, various researchers have studied the characteristics of nano-scale dust explosions, including the effects of metal and plastic dust (Boilard et al. 2013; Mittal 2014; Gao et al. 2015; Turkevich et al. 2015). The violence and sensitivity of the explosion increase as the coal dust particle size

Huilin Liu

734817194@qq.com

1 School of Emergency Management and Safety Engineering, China University of Mining and Technology (Beijing), Beijing 100083, China decreases (Sapko et al. 2007). However, nano-sized dust may not follow the above rules that were defined for microsized dust (Eckhoff 2012). Thus, there is a clear need for further research in the areas of nano-sized coal dust and coal dust-gas explosions.

In recent decades, experts and scholars have focused on micron-sized coal dust and methane-coal dust explosions. For example, Eckhoff (2009) pointed out that the dust particle size, concentration, and turbulence intensity are the main factors affecting dust explosions. Gao et al. (2010) studied the lower limit density and pressure characteristics of coal dust explosions using a $20 \mathrm{~L}$ spherical vessel and found that the coal dust particle size is inversely proportional to the explosion violence and sensitivity. Proust et al. (2007) tested the explosive violence of several types of dust using a "20 L sphere" and a standard "ISO $1 \mathrm{~m}^{3}$ vessel", systematically comparing and analyzing the experimental differences. Addai et al. $(2015,2016)$ performed explosion experiments on various dust/gas mixtures using an improved $\mathrm{G}-\mathrm{G}$ furnace and a $20 \mathrm{~L}$ sphere. The 
results show that addition of a small amount of dust, gas or solvent significantly reduced the lower explosive limit of the mixture and increased its explosibility. Liu et al. (2010) studied coal dust-air mixture explosions under weak ignition conditions in a horizontal experimental tube. The researchers measured the maximum explosion overpressure, the propagation velocity of the pressure wave along the tube and the minimum concentration of coal dust required for an explosion. Various researchers have studied the flammabilities of methane-coal dust mixtures (Amyotte et al. 1991, 1993; Cashdollar 1996; Rockwell and Rangwala 2013; Ajrash et al. 2016, 2017). The lower ignition limit of the mixture decreases as the ignition energy increases. The presence of methane, coal dust particle size reduction, and increased coal dust volatility all reduce the lower explosion limit.

Although scholars have conducted substantial research on dust and methane-dust explosions, differences in experimental methods, testing methods, and research objectives have led to substantial differences in conclusions. For example, some scholars believe that the explosion intensity of a mixture of dust and combustible gas is not only greater than that of dust alone but also larger than that of the combustible gas (Pilão et al. 2006; Denkevits et al. 2007; Dufaud et al. 2008). However, other scholars believe that the flammable gas alone exhibits the highest explosion intensity of the three cases (Garcia-Agreda et al. 2011; Sanchirico et al. 2011). Therefore, there are still significant areas of dust and methane-dust explosion research worthy of study.

At present, there are few studies on the explosion of nano-sized coal dust and methane-coal dust mixtures. In this study, five different particle sizes $(800 \mathrm{~nm}, 1200 \mathrm{~nm}$, $45 \mu \mathrm{m}, 60 \mu \mathrm{m}$, and $75 \mu \mathrm{m}$ ) were used in a pipe test apparatus with a length of $2000 \mathrm{~mm}$ and an inner diameter of $88 \mathrm{~mm}$. Coal dust and methane-coal dust explosion experiments were conducted, and the resulting explosion pressure characteristic parameters were compared and analyzed to provide theoretical support for coal dust explosion prevention and production safety.

\section{Experiments}

\subsection{Coal samples}

\subsubsection{Proximate analysis of coal samples}

The experimental samples were anthracites from the Yangquan Coal Mine, Shanxi Province, China. Before proximate analysis, the coal samples were dried and dehydrated in a constant-temperature drying oven at $80{ }^{\circ} \mathrm{C}$ for $24 \mathrm{~h}$. They were then tested using a GF-A6 automatic coal proximate analyzer. The results show that the $\mathrm{M}_{\mathrm{ad}}$, $\mathrm{A}_{\mathrm{ad}}, \mathrm{V}_{\mathrm{ad}}, \mathrm{FC}$ and others of coal samples are $3.9 \%, 8.58 \%$, $9.37 \%, 78.11 \%$ and $0.04 \%$ respectively.

\subsubsection{Coal sample particle size characteristics}

The particle size characteristics of coal samples were tested using a BT-9300LD laser particle sizer. The results are shown in Table 1. The average coal sample particle size was reflected by the median particle size, $\mathrm{D}_{50}$. The five coal samples met the experimental design particle size requirements.

\subsubsection{Coal sample particle surface characteristics}

The surface characteristics of coal samples with various particle sizes were observed using a Hitachi SU-8010 scanning electron microscope. Its high-voltage limit $(30 \mathrm{kV})$ resolution was $1.0 \mathrm{~nm}$, it offered low acceleration voltage imaging capabilities, and it could meet scanning requirements. The coal sample scanning test results are shown in Fig. 1.

Figure 1 shows nano-sized coal particles enlarged 20000 times and micro-sized coal particles enlarged 2000 times. Smaller coal dust particles tended to stick together more than larger ones. Nano-sized particle edges were round and smooth. As shown in Fig. 2c, d, Bu et al. (2020) also found that smaller particles exhibited stronger intermolecular forces that affect coagulation. The micro-sized particles were relatively dispersed. Most particles were in the form of flakes and particle edges and corners were clearly demarcated. Typically, nano-sized coal dust surfaces were flatter and smoother than their micro-sized counterparts.

\subsection{Experimental apparatus}

The explosion experiments were performed in a stainlesssteel pipe with an inner diameter of $88 \mathrm{~mm}$, a wall thickness of $10 \mathrm{~mm}$, a pressure resistance of $18 \mathrm{MPa}$, a total length of $2000 \mathrm{~mm}$ and an effective volume of $11.92 \mathrm{~L}$.

Table 1 Coal sample particle size test results

\begin{tabular}{lllll}
\hline $\begin{array}{l}\text { Coal } \\
\text { sample } \\
\text { number }\end{array}$ & $\begin{array}{l}\mathrm{D}_{50} \\
\text { Median } \\
\text { particle } \\
\text { size }(\mu \mathrm{m})\end{array}$ & $\begin{array}{c}\mathrm{D}(4,3) \mathrm{V} \\
\text { olume mean } \\
\text { diameter } \\
(\mu \mathrm{m})\end{array}$ & $\begin{array}{l}\mathrm{D}(3,2) \\
\text { Surface } \\
\text { mean } \\
\text { diameter } \\
(\mu \mathrm{m})\end{array}$ & $\begin{array}{l}\text { SSA } \\
\text { Specific } \\
\text { surface } \\
\text { area }\left(\mathrm{m}^{2} /\right. \\
\mathrm{kg})\end{array}$ \\
\hline 1 & 0.825 & 0.916 & 0.856 & 1467 \\
2 & 1.207 & 1.312 & 1.268 & 1059 \\
3 & 45.36 & 46.78 & 46.27 & 213 \\
4 & 61.28 & 62.17 & 61.59 & 189 \\
5 & 74.82 & 75.72 & 75.14 & 174 \\
\hline
\end{tabular}




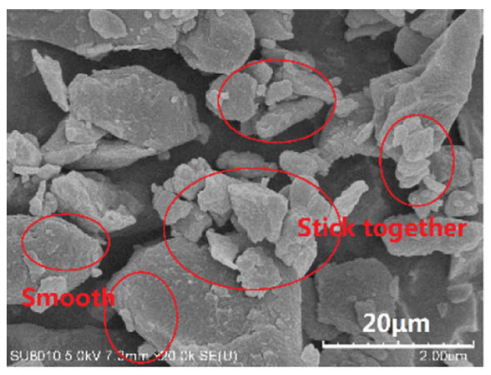

(a) $800 \mathrm{~nm}(\times 20000)$

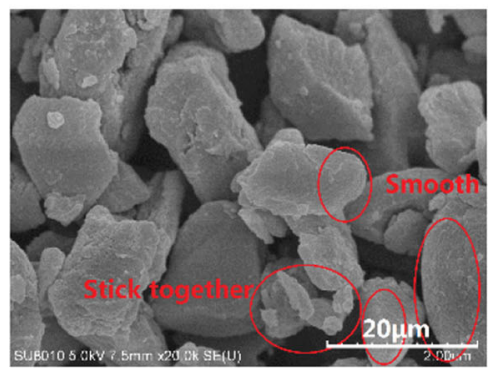

(b) $1200 \mathrm{~nm}(\times 20000)$

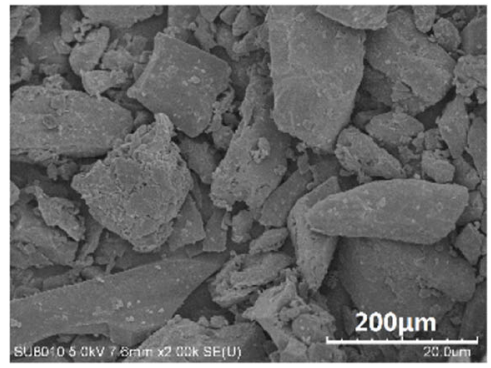

(c) $45 \mu \mathrm{m}(\times 2000)$

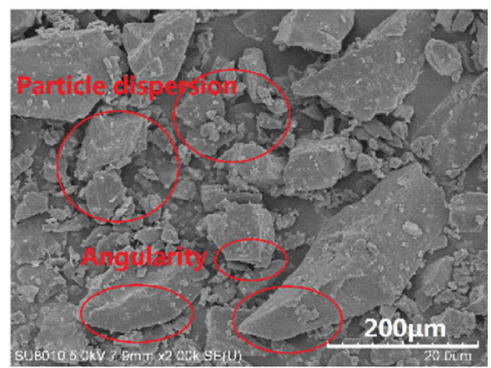

(d) $60 \mu \mathrm{m}(\times 2000)$

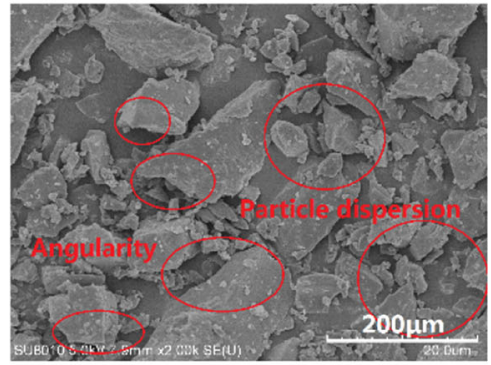

(e) $75 \mu \mathrm{m}(\times 2000)$

Fig. 1 SEM pictures of coal samples
The experimental system mainly consisted of four parts: (1) an experimental pipe-based container; (2) a data acquisition and control system; (3) a coal dust dispersion system; and (4) an ignition system. The experimental apparatus is shown in Fig. 3. Four pressure sensor interfaces and four dust nozzle interfaces were arranged on a single pipe, where they were evenly distributed throughout the section. The first dust nozzle interface was $125 \mathrm{~mm}$ from the ignition point. The distance between two interfaces was $250 \mathrm{~mm}$, as shown in Fig. 4. In order to accurately study the pressure characteristics of coal dust explosions, the device used a coal dust dispersion system to spray the powder. This ensured that the coal dust was evenly dispersed inside the pipe. The system was mainly composed of an air compressor, gas storage volume, solenoid valve, check valve, nozzle, pressure gauge, etc. Each nozzle was supplied by an independent gas storage volume to ensure that the same pressure was provided at each nozzle and that the spray powder pressure could be controlled. Since the nozzles were close together, each one needed to cover only a small volume. Since the dusting pressure was large, the coal dust was assumed to be uniformly dispersed inside the pipe. Further device details are shown in Fig. 4. The ignition system consisted of a highenergy igniter, ignition rod, ignition line tube, external trigger switch, etc. Ignition I output was $35 \mathrm{~mJ}$, ignition II output was 3-20 J, and the ignition energy of the experiment was $20 \mathrm{~J}$. Other technical parameters include the initial vessel pressure $(101.325 \mathrm{kPa})$ and the dust dispersion pressure (2.0 MPa).

\subsection{Dust explosion conditions}

Dust explosions must meet five specific conditions, which are typically represented using the dust explosion pentagon. The conditions for this experiment are shown in Fig. 5: (1) the sample was coal dust, which is flammable; (2) coal dust can be violently oxidized with oxygen in the air; (3) coal dust was suspended in the air by using a dispersion system to form a dust cloud with a particular coal concentration; (4) a $20 \mathrm{~J}$ spark ignition was used; (5) the dust cloud was formed inside an $11.92 \mathrm{~L}$ pipe.

\section{Results and discussion}

\subsection{Micro-nano coal dust explosion pressure characteristics}

\subsubsection{Coal dust explosion pressure characteristics}

The mass concentrations of coal dust used in the experiments were $100 \mathrm{~g} / \mathrm{m}^{3}, 250 \mathrm{~g} / \mathrm{m}^{3}, 500 \mathrm{~g} / \mathrm{m}^{3}, 750 \mathrm{~g} / \mathrm{m}^{3}$, and 


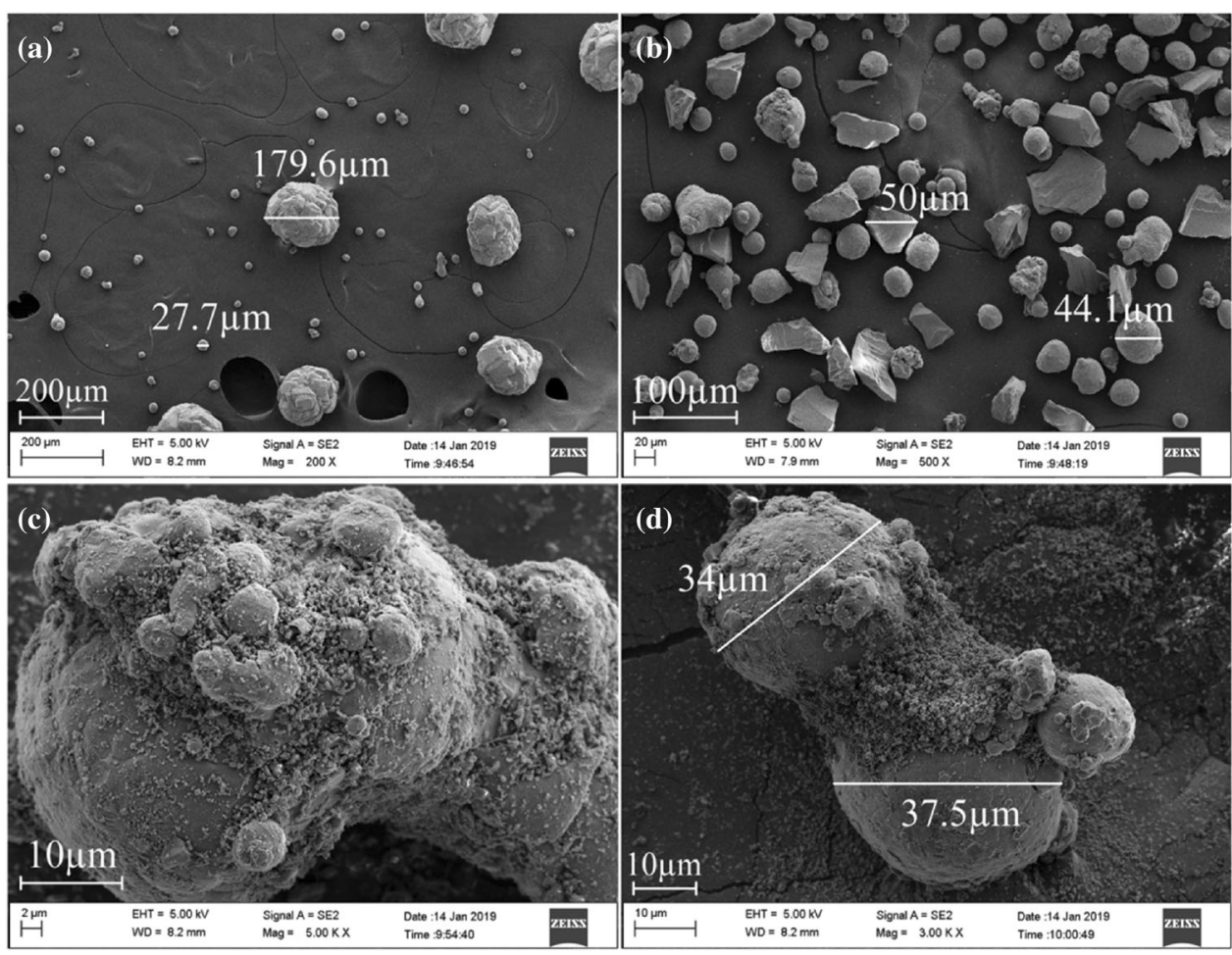

Fig. 2 SEM images of $\mathrm{Al}$ particles mixed with $30 \% \mathbf{a}<150 \mu \mathrm{m}, \mathbf{b}<45 \mu \mathrm{m}, \mathbf{c} 2.5 \mu \mathrm{m}$ and $\mathbf{d ~} 50 \mathrm{~nm} \mathrm{Al}_{2} \mathrm{O}_{3}$ powder (Bu et al. 2020)

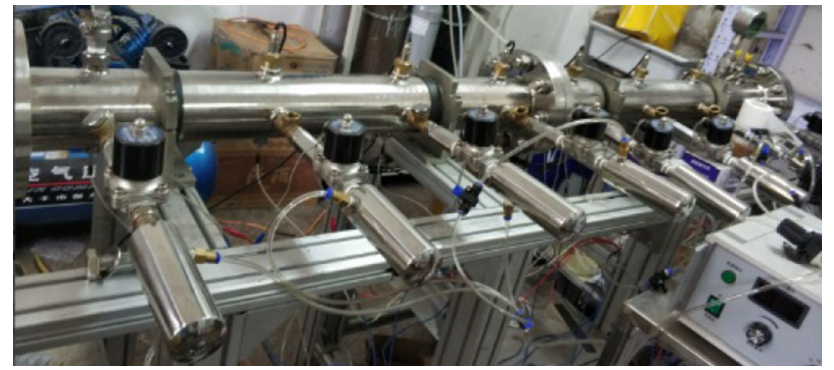

Fig. 3 Experimental apparatus

$1000 \mathrm{~g} / \mathrm{m}^{3}$. The corresponding coal dust quantities were $1.192 \mathrm{~g}, 2.980 \mathrm{~g}, 5.960 \mathrm{~g}, 8.940 \mathrm{~g}$, and $11.920 \mathrm{~g}$. Explosion pressure-time curves measured using various micronano coal dust concentrations are shown in Fig. 6.

Figure 6 shows that the explosion pressure curves follow similar trends, regardless of the coal dust concentration and particle size. In Fig. 6a, the explosion pressure curve

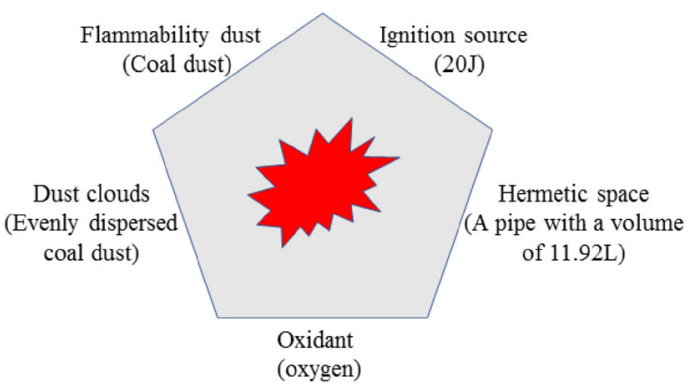

Fig. 5 Dust explosion pentagon

can be divided into three stages. In the preparation stage (t1), which occurs after dusting but before ignition, the pressure approaches 0 and remains unchanged. The second stage is indicated by a pressure increase (t2) that occurs after ignition and proceeds until a maximum is reached. The final stage is marked by a pressure decrease ( $t 3)$. The

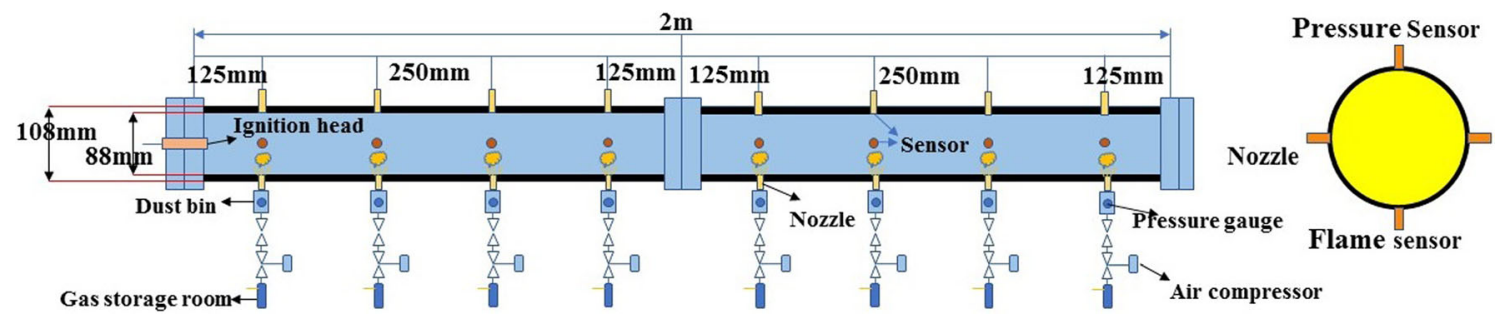

Fig. 4 Pipe size and sensor positions 


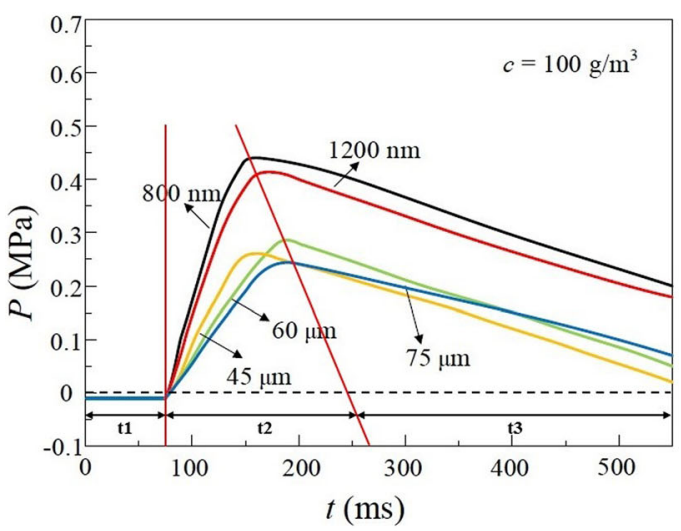

(a) $c=100 \mathrm{~g} / \mathrm{m}^{3}$

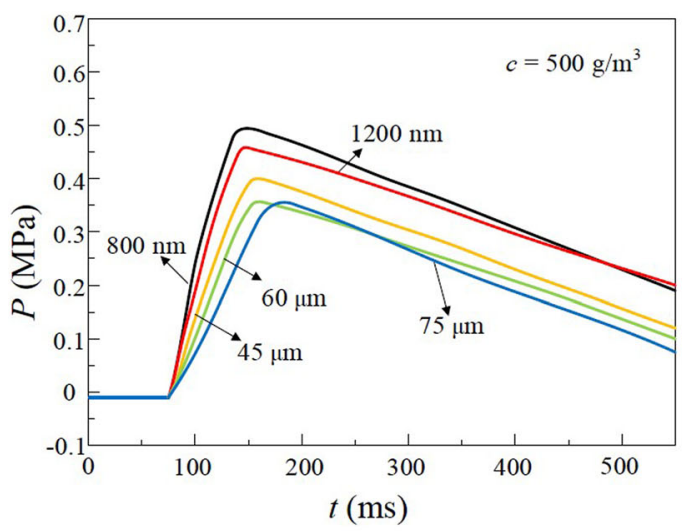

(c) $c=500 \mathrm{~g} / \mathrm{m}^{3}$

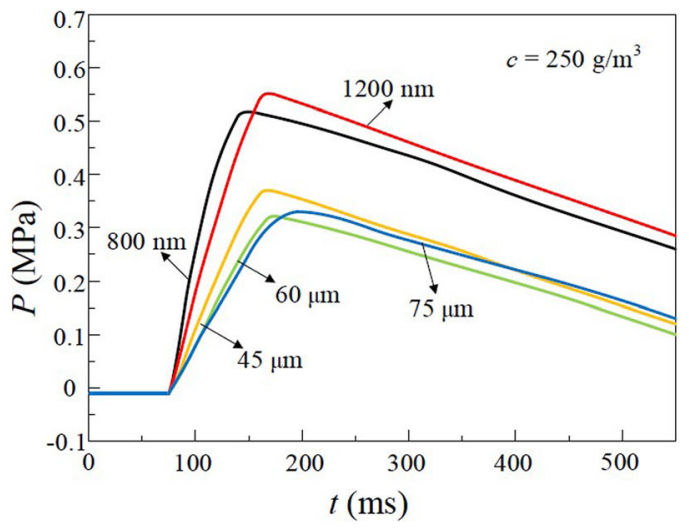

(b) $c=250 \mathrm{~g} / \mathrm{m}^{3}$

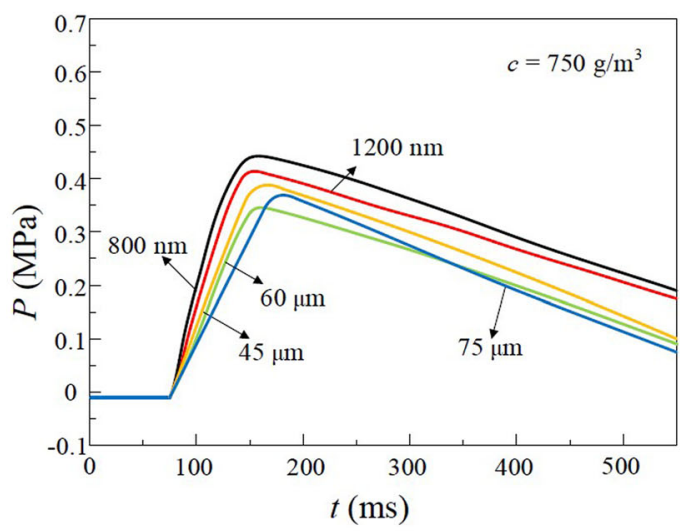

(d) $c=750 \mathrm{~g} / \mathrm{m}^{3}$

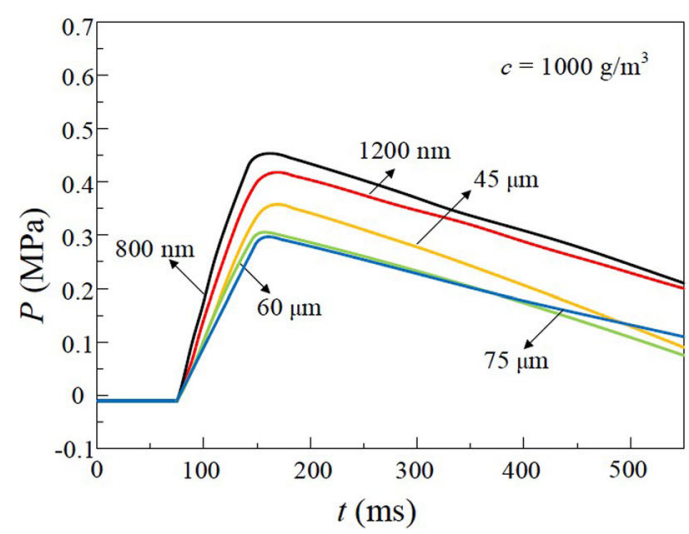

(e) $c=750 \mathrm{~g} / \mathrm{m}^{3}$

Fig. 6 Coal dust explosion pressure-time curves

pressure decreases slowly until it reaches steady state. Typically, smaller particle sizes produce higher maximum explosion pressures and rates of pressure rise. The relationship between the maximum explosion pressure and the optimal concentration is affected by the particle size.

\subsubsection{Relationship between the maximum rate of pressure rise and coal dust explosion characteristics}

The rate of pressure rise $(d p / d t)_{m}$ of the explosion (Myers 2008) is calculated by applying Eq. (1) to the pressure rise curve section recorded after the explosion. The pressure rise curve section can be obtained from the pressure-time curve in Fig. 4. 


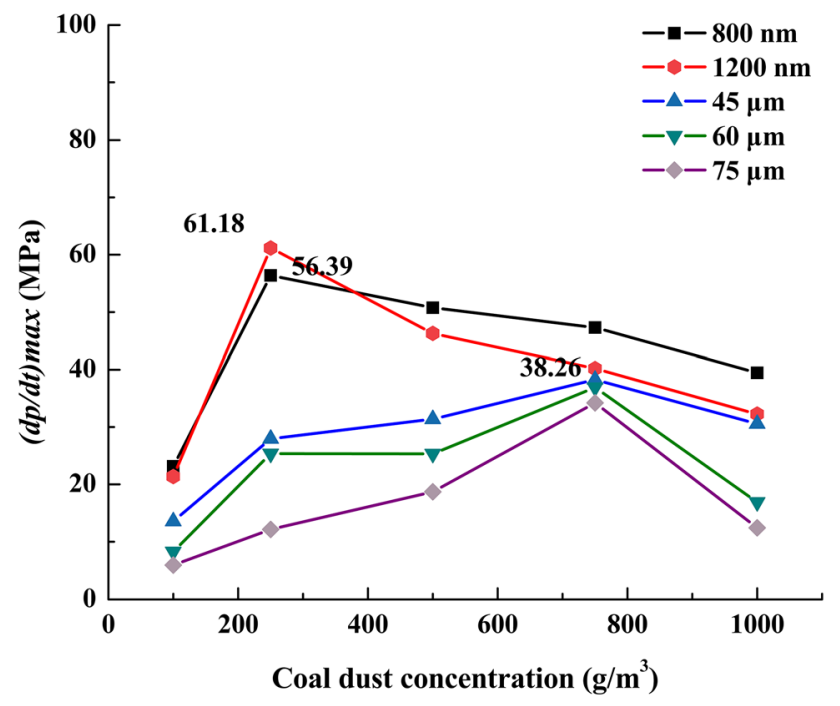

Fig. 7 Relationship between the maximum rate of pressure rise and the coal dust concentration

$\left(\frac{d p}{d t}\right)_{m}=\left(\frac{P_{i+1}-P_{i}}{t_{i+1}-t_{i}}\right)_{\max }$

The maximum rates of pressure rise for various particle sizes and concentrations are shown in Fig. 7. The maximum rates of pressure rise for $800 \mathrm{~nm}$ and $1200 \mathrm{~nm}$ coal dust explosions are $61.18 \mathrm{MPa} / \mathrm{s}$ and $56.39 \mathrm{MPa} / \mathrm{s}$, while the maximum value for $45 \mu \mathrm{m}$ coal dust is $38.26 \mathrm{MPa} / \mathrm{s}$. The maximum rate of pressure rise within a nano-sized coal dust explosion is almost 1.5 times that within a micro-sized coal dust explosion. The maximum rate of pressure rise for nano-sized coal dust is always greater than that for micro-sized coal dust at the same concentration.

\subsubsection{Coal dust explosion deflagration index characteristics}

The deflagration index $K_{s t}$ is an important parameter for studying explosive violence. It can be calculated using Eq. (2) (Amyotte and Eckhoff 2010; Abbasi and Abbasi 2007).

$K_{s t}=\left(\frac{d p}{d t}\right)_{\max } \cdot V^{\frac{1}{3}}$

where $K_{s t}$ is the coal dust deflagration index, $\mathrm{MPa} /(\mathrm{m} \cdot \mathrm{s})$; $(d p / d t)_{\max }$ is the maximum rate of pressure rise within the coal dust explosion in $\mathrm{MPa} / \mathrm{s}$; and $V$ is the explosive container volume in $\mathrm{m}^{3}$.

The $K_{s t}$ value can be used to divide the dust explosion hazard into four grades [24] as shown in Table 2, which is modified from Fumagalli et al. (2016).
Table 2 Dust explosion hazard grading standard (Fumagalli et al. 2016)

\begin{tabular}{lll}
\hline Range & Grade & Explosibility \\
\hline$K_{\text {st }}=0$ & $\mathrm{St}_{0}$ & Non-explosible \\
$0<K_{\text {st }}<20$ & $\mathrm{St}_{1}$ & Weak \\
$20 \leq K_{\text {st }}<30$ & $\mathrm{St}_{2}$ & Strong \\
$K_{\text {st }} \geq 30$ & $\mathrm{St}_{3}$ & Very strong \\
\hline
\end{tabular}

Table 3 Micro-nano coal dust explosion characteristics and risk level in the pipe

\begin{tabular}{lllll}
\hline $\begin{array}{l}\text { Particle } \\
\text { size }\end{array}$ & $\begin{array}{l}P_{\max } \\
(\mathrm{MPa})\end{array}$ & $\begin{array}{l}(d P / d t)_{\max } \\
(\mathrm{MPa} / \mathrm{s})\end{array}$ & $\begin{array}{l}K_{\mathrm{st}}(\mathrm{MPa} / \\
(\mathrm{m} \cdot \mathrm{s}))\end{array}$ & $\begin{array}{l}\text { Hazard } \\
\text { grade }\end{array}$ \\
\hline $800 \mathrm{~nm}$ & 0.52 & 56.39 & 12.88 & $\mathrm{St}_{1}$ \\
$1200 \mathrm{~nm}$ & 0.55 & 61.18 & 13.97 & $\mathrm{St}_{1}$ \\
$40 \mu \mathrm{m}$ & 0.40 & 38.26 & 8.74 & $\mathrm{St}_{1}$ \\
$60 \mu \mathrm{m}$ & 0.36 & 36.91 & 8.43 & $\mathrm{St}_{1}$ \\
$75 \mu \mathrm{m}$ & 0.37 & 34.21 & 7.81 & $\mathrm{St}_{1}$ \\
\hline
\end{tabular}

Equation (2) can be used to determine the coal dust explosion hazard grade and characteristic parameters for a given particle size, as shown in Table 3. The maximum deflagration indices for $800 \mathrm{~nm}$ and $1200 \mathrm{~nm}$ coal dust are $12.88 \mathrm{MPa} /(\mathrm{m} \cdot \mathrm{s})$ and $13.97 \mathrm{MPa} /(\mathrm{m} \cdot \mathrm{s})$. The maximum deflagration index for micro-sized coal dust is $8.74 \mathrm{MPa} /(\mathrm{m} \cdot \mathrm{s})$, which is between $0 \mathrm{MPa} /(\mathrm{m} \cdot \mathrm{s})$ and $20 \mathrm{MPa} /(\mathrm{m} \cdot \mathrm{s})$. Therefore, the explosion hazard grade is $\mathrm{St}_{1}$ and the explosibility is weak. However, the $K_{s t}$ value increases as the coal dust particle size decreases, which proves that the particle size has a clear impact on the explosion risk.

\subsubsection{Maximum coal dust explosion pressure characteristics}

As shown in Fig. 8, different particle sizes produce significantly different experimental maximum explosion pressures. At a given coal dust concentration, the maximum explosion pressure decreases as the particle size increases. For example, the maximum pressure of an $800 \mathrm{~nm}$ coal dust explosion is almost 1.5 times that of an explosion with $75 \mu \mathrm{m}$ particles. This is because within a certain range, a smaller particle size contributes to dispersion of the coal dust, allowing more coal dust to participate in the explosion (Eckhoff 2009). Smaller particle sizes contribute more to volatilization ( $\mathrm{Li}$ et al. 2016). Therefore, the coal dust particle size is inversely proportional to the explosion pressure. The maximum explosion pressure is $0.55 \mathrm{MPa}$ for $1200 \mathrm{~nm}$ coal dust at a 


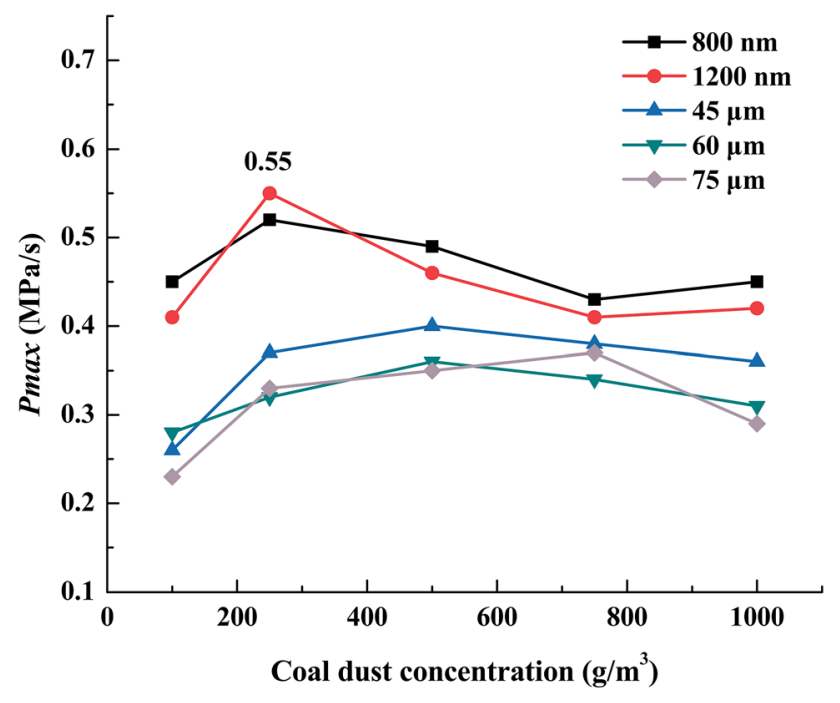

Fig. 8 The maximum coal dust explosion pressure

concentration of $250 \mathrm{~g} / \mathrm{m}^{3}$. Of the five concentrations tested experimentally, the optimum explosion concentration is $250 \mathrm{~g} / \mathrm{m}^{3}$.

\subsection{Comparison of coal dust and methane-coal dust explosion pressure characteristics}

\subsubsection{Methane-coal dust explosion pressure characteristics}

The same experimental apparatus was used in methanecoal dust mixture explosion experiments. The pipe was filled with $7 \%$ methane in air. Other experimental steps were consistent with the coal dust explosion experiments. Explosion pressure-time curves measured with various micro and nano methane-coal dust concentrations are shown in Fig. 9.

Figure 9 shows that the relationships that govern methane-coal dust explosions are similar to those that govern coal dust explosions. However, the maximum explosion pressure and maximum rate of pressure rise are greater in the former, which indicates that the coal dust-gas mixture explosion is more dangerous.

\subsubsection{Comparison of maximum rate of pressure rise characteristics}

The rate of pressure rise $(d p / d t)_{m}$ of a methane-coal dust explosion can be calculated using Eq. (1) to obtain the relationship between maximum rate of pressure rise and the methane-coal dust concentration, as shown in Fig. 10. The maximum rates of pressure rise of methane-coal dust explosions with $800 \mathrm{~nm}$ and $1200 \mathrm{~nm}$ particles are $186.92 \mathrm{MPa} / \mathrm{s}$ and $152.27 \mathrm{MPa} / \mathrm{s}$, respectively. The maximum value for a methane-coal dust explosion with micro-sized particles is $92.81 \mathrm{MPa}$. Thus, the maximum rate of pressure rise for a nano-sized methane-coal dust mixture explosion is more than twice that of a micro-sized coal dust explosion. In addition, it is always greater than that for micro-sized coal dust at the same concentration. Of the five concentrations tested, $100 \mathrm{~g} / \mathrm{m}^{3}$ produced the fastest rate of pressure rise, which indicates that the optimum methane-coal dust concentration is $100 \mathrm{~g} / \mathrm{m}^{3}$ in this experimental apparatus.

The maximum rates of explosion pressure rise for coal dust and methane-coal dust explosions are shown in Fig. 11. The rate of pressure rise of a coal dust explosion reaches its maximum value of $61.18 \mathrm{MPa} / \mathrm{s}$ when the particle size is $1200 \mathrm{~nm}$ and the concentration is $250 \mathrm{~g} / \mathrm{m}^{3}$. The rate of pressure rise of methane-coal dust explosion reaches its maximum value of $186.92 \mathrm{MPa} / \mathrm{s}$ when the particle size is $800 \mathrm{~nm}$ and the concentration is $100 \mathrm{~g} / \mathrm{m}^{3}$. This shows that the rate of pressure rise is maximized with nano-sized coal dust. The maximum rate of pressure rise of the methane-coal dust explosion is much higher than that for coal dust alone. Some values for the former are even three times those for the latter.

\subsubsection{Comparison of deflagration index characteristics}

The deflagration index $K_{s t}$ of a methane-coal dust explosion can be calculated using Eq. (2). This allows one to determine the methane-coal dust explosion hazard grade and explosion characteristic parameters for various particle sizes, as shown in Table 4. The deflagration indices of $800 \mathrm{~nm}$ and $1200 \mathrm{~nm}$ methane-coal dust mixtures are $42.62 \mathrm{MPa} /(\mathrm{m} \cdot \mathrm{s})$ and $34.72 \mathrm{MPa} /(\mathrm{m} \cdot \mathrm{s})$, both of which are greater than $30 \mathrm{MPa} /(\mathrm{m} \cdot \mathrm{s})$. Therefore, the explosion hazard grade is $\mathrm{St}_{3}$ and the explosibility is very strong. The deflagration indices of methane-coal dust mixtures with particle sizes of $40 \mu \mathrm{m}$ and $60 \mu \mathrm{m}$ are between 20 and $30 \mathrm{MPa} /(\mathrm{m} \cdot \mathrm{s})$. Therefore, their explosion hazard grade is $\mathrm{St}_{2}$ and their explosibility is strong. The explosion hazard increases substantially upon adding methane.

Deflagration indices for coal dust and methane-coal dust mixtures are compared in Fig. 12. When the particle size is $1200 \mathrm{~nm}$ and the concentration is $250 \mathrm{~g} / \mathrm{m}^{3}$, the deflagration index of a coal dust explosion reaches a maximum of $13.97 \mathrm{MPa} /(\mathrm{m} \cdot \mathrm{s})$ and a hazard grade of $\mathrm{St}_{1}$. When the particle size is $800 \mathrm{~nm}$ and the concentration is $100 \mathrm{~g} / \mathrm{m}^{3}$, the deflagration index of a methane-coal dust explosion reaches a maximum of $42.62 \mathrm{MPa} /(\mathrm{m} \cdot \mathrm{s})$ and the hazard grade is $\mathrm{St}_{3}$. This shows that addition of methane to a coal dust explosion can have a large impact on the deflagration index. The deflagration index decreases as the coal dust particle size increases and that of a set of nano-sized particles is substantially larger than with micron-sized 


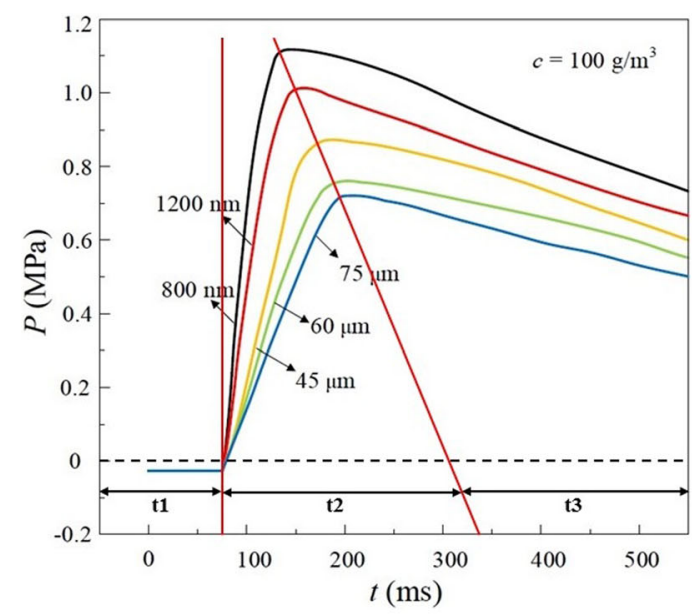

(a) $c=100 \mathrm{~g} / \mathrm{m}^{3}$

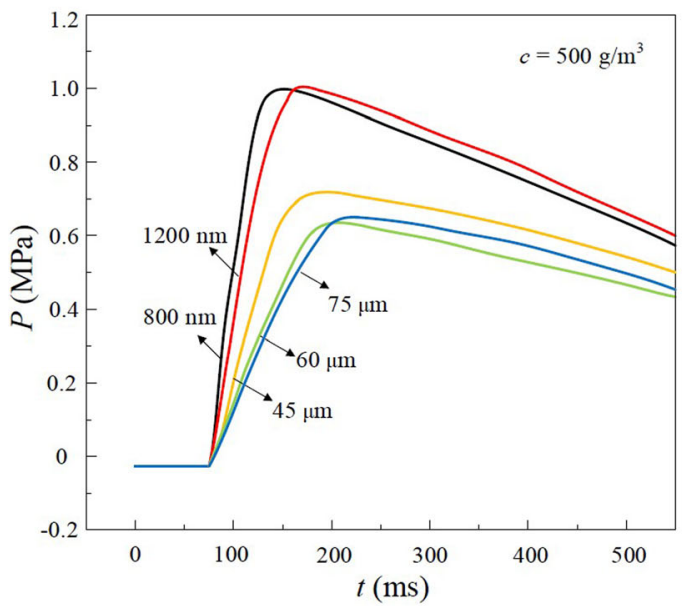

(c) $c=500 \mathrm{~g} / \mathrm{m}^{3}$

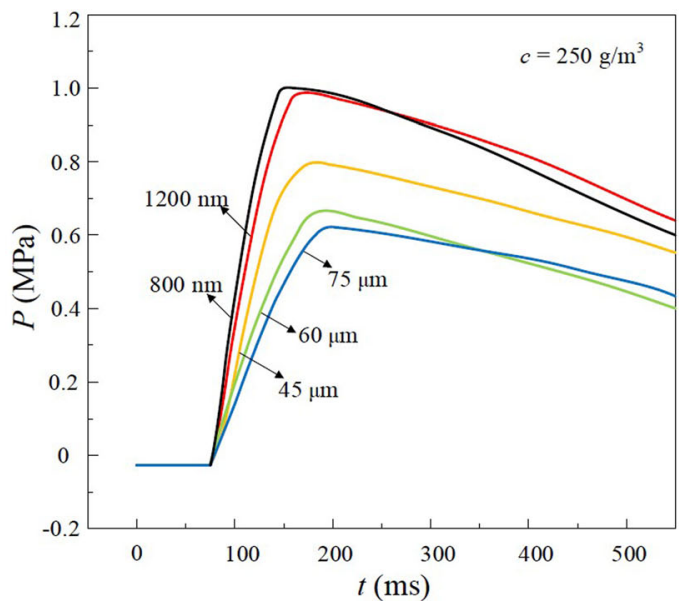

(b) $c=250 \mathrm{~g} / \mathrm{m}^{3}$

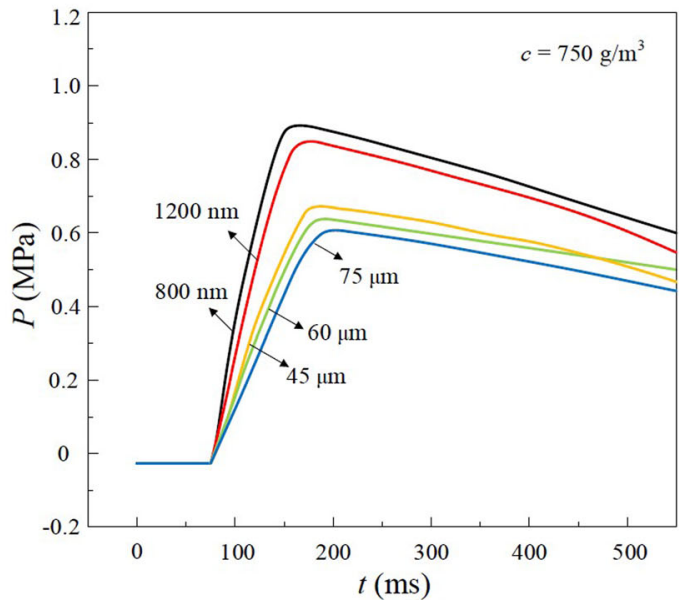

(d) $c=750 \mathrm{~g} / \mathrm{m}^{3}$

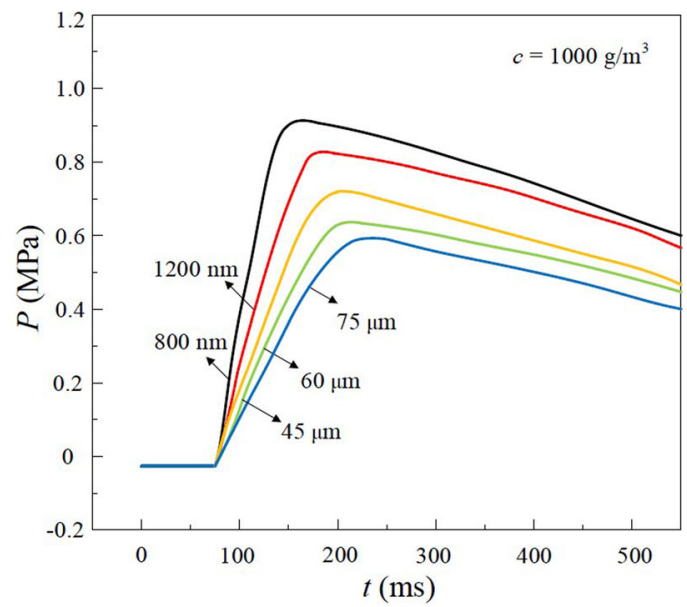

(e) $c=1000 \mathrm{~g} / \mathrm{m}^{3}$

Fig. 9 Methane-coal dust explosion pressure-time curves

particles. Some values are even more than three times larger. The increase in dust explosion intensity is attributed to an increase in the combustion kinetic energy of the mixture after the combustible gas is mixed (Dufaud et al. 2008). On the other hand, strong initial turbulence causes the combustion rate of the gas to rise rapidly within the 


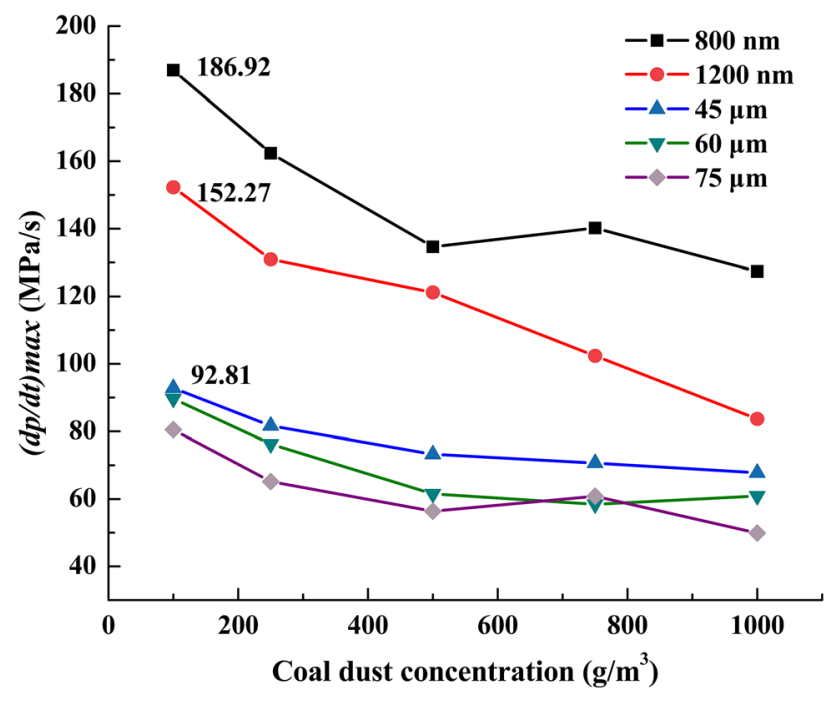

Fig. 10 Relationship between the maximum rate of pressure rise and the methane-coal dust concentration

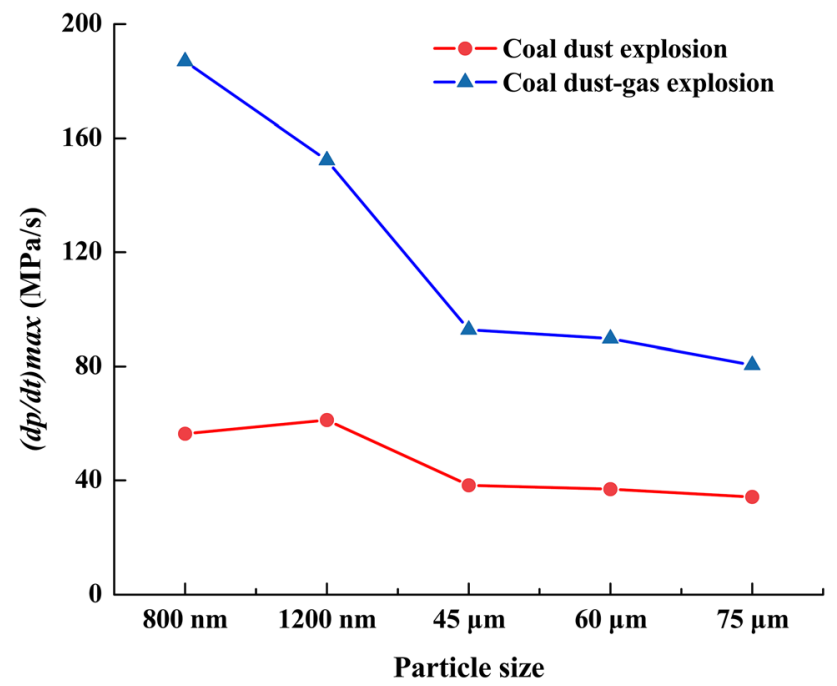

Fig. 11 Comparison of maximum rates of pressure rise

Table 4 Micro-nano methane-coal dust explosion characteristics and risk levels in the pipe

\begin{tabular}{lllll}
\hline $\begin{array}{l}\text { Particle } \\
\text { size }\end{array}$ & $\begin{array}{l}P_{\max } \\
(\mathrm{MPa})\end{array}$ & $\begin{array}{l}(d P / d t)_{\max } \\
(\mathrm{MPa} / \mathrm{s})\end{array}$ & $\begin{array}{l}K_{\mathrm{st}}(\mathrm{MPa} / \\
(\mathrm{m} \cdot \mathrm{s}))\end{array}$ & $\begin{array}{l}\text { Hazard } \\
\text { grade }\end{array}$ \\
\hline $800 \mathrm{~nm}$ & 1.12 & 186.92 & 42.62 & $\mathrm{St}_{3}$ \\
$1200 \mathrm{~nm}$ & 1.04 & 152.27 & 34.72 & $\mathrm{St}_{3}$ \\
$40 \mu \mathrm{m}$ & 0.89 & 92.81 & 21.62 & $\mathrm{St}_{2}$ \\
$60 \mu \mathrm{m}$ & 0.76 & 89.67 & 20.44 & $\mathrm{St}_{2}$ \\
$75 \mu \mathrm{m}$ & 0.72 & 80.49 & 18.35 & $\mathrm{St}_{1}$ \\
\hline
\end{tabular}

mixture, which leads to an increase in the explosive strength of the mixture (Sanchirico et al. 2011).

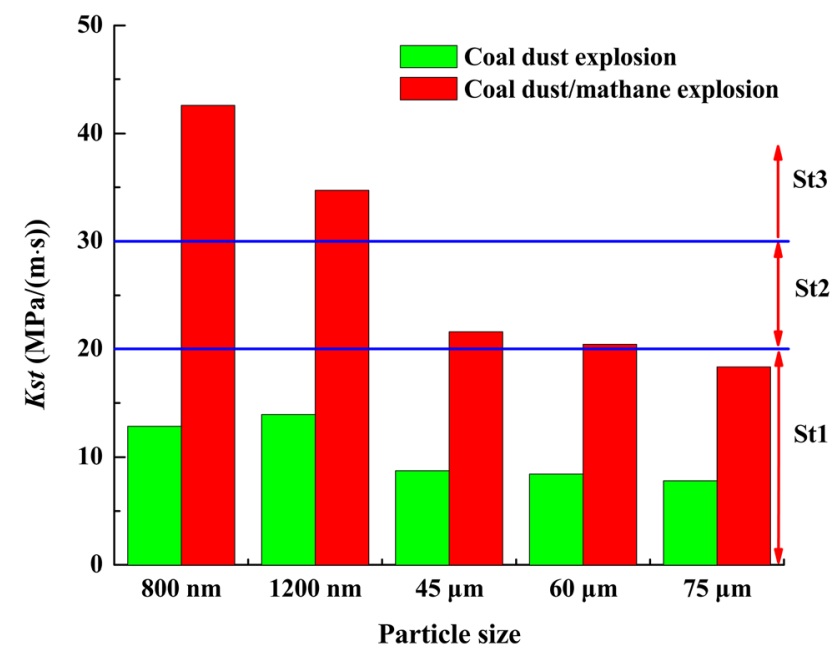

Fig. 12 Deflagration index comparison

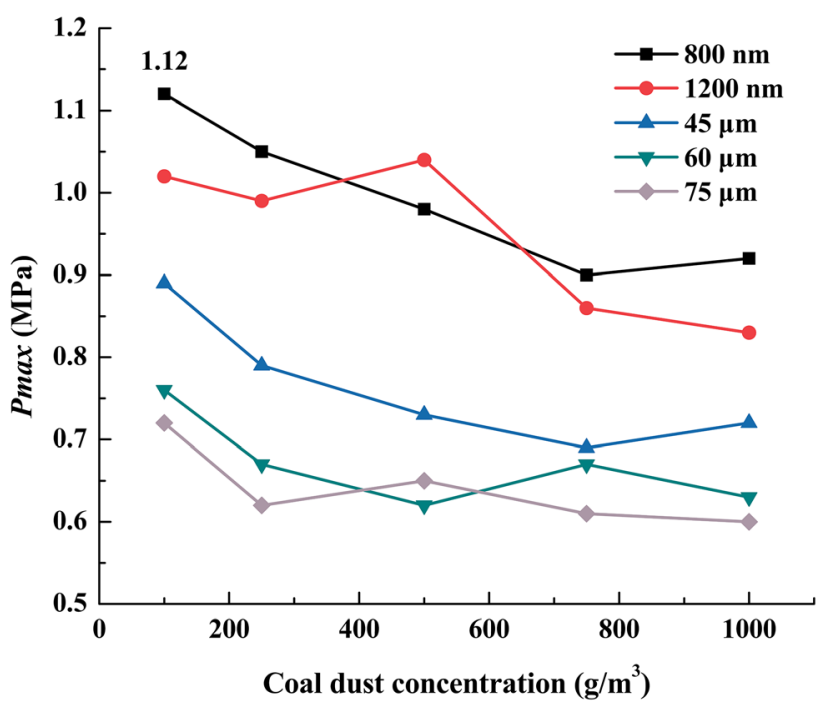

Fig. 13 Maximum pressures of various methane-coal dust explosions

\subsubsection{Comparison of maximum pressure characteristics}

The maximum pressures of methane-coal dust explosions started with various dust concentrations are shown in Fig. 13. For a given coal dust concentration, the maximum methane-coal dust explosion pressure decreases as the particle size increases. The maximum explosion pressure is reached at a particle size of $800 \mathrm{~nm}$ and concentration of $100 \mathrm{~g} / \mathrm{m}^{3}(1.12 \mathrm{MPa})$. The maximum pressure of a microsized methane-coal dust explosion is less than that of an explosion with nano-sized particles.

Maximum explosion pressures for coal dust and methane-coal dust systems are shown in Fig. 14. When the particle size is $1200 \mathrm{~nm}$ and the concentration is $250 \mathrm{~g} / \mathrm{m}^{3}$, the coal dust explosion pressure reaches its maximum of 


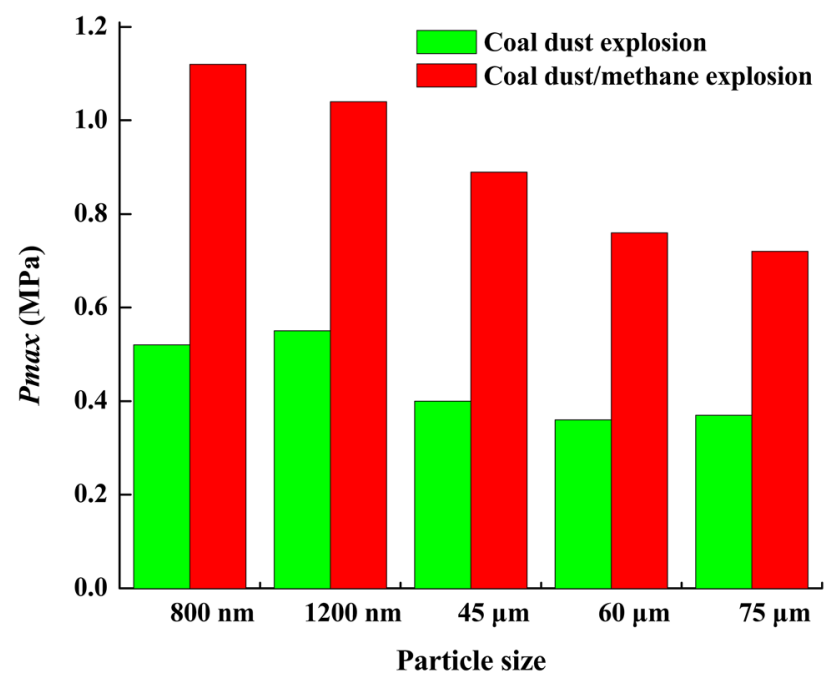

Fig. 14 Comparison of maximum explosion pressures

$0.55 \mathrm{MPa}$. When the particle size is $800 \mathrm{~nm}$ and the coal dust concentration is $100 \mathrm{~g} / \mathrm{m}^{3}$, the methane-coal dust explosion pressure reaches its maximum of $1.12 \mathrm{MPa}$. This shows that the maximum nano-sized particle explosion pressure is greater than that of a micro-sized particle and the maximum explosion pressure decreases as the particle size increases. When the coal dust particle size and concentration are held constant, the maximum explosion pressure of a methane-coal dust mixture is approximately double that of coal dust alone.

\section{Conclusions}

(1) The explosive characteristics of coal dust in the pipe system are closely related to the particle size and concentration. The explosion pressure follows trends related to these variables. The maximum explosion pressure was greater and the time required to reach this maximum was less with nano-sized coal dust than with micron-sized dust. At a given concentration, the nano-sized coal dust explosion pressure, maximum rate of pressure rise, and deflagration index are all larger than with micro-sized coal dust, indicating that a nano-sized coal dust explosion is more dangerous.

(2) Of the five different concentrations tested, the optimum nano-sized coal dust concentration in the system was $250 \mathrm{~g} / \mathrm{m}^{3}$. Under these conditions, the maximum explosion pressure was $0.55 \mathrm{MPa}$, the maximum rate of pressure rise was $61.18 \mathrm{MPa} / \mathrm{s}$, and the deflagration index was $13.97 \mathrm{MPa} /(\mathrm{m} \cdot \mathrm{s})$. Therefore, the coal dust explosion hazard grade was $\mathrm{St}_{1}$, and the explosibility was weak.
(3) When a 7\% methane-air mixture was added to the coal dust, the optimum concentration was $100 \mathrm{~g} / \mathrm{m}^{3}$, the maximum explosion pressure was $1.12 \mathrm{MPa}$, and the maximum rate of pressure rise was $186.92 \mathrm{MPa} /$ s. The maximum explosion pressure and rate of pressure rise were approximately two and three times larger, respectively, than with coal dust alone. The maximum deflagration index of the methanecoal dust mixture explosion was $42.62 \mathrm{MPa} /(\mathrm{m} \cdot \mathrm{s})$. Therefore, the explosion hazard grade was $\mathrm{St}_{3}$ and the explosibility was very strong. This shows that the presence of methane increases the coal dust explosive power substantially.

Acknowledgements This research was supported by the National Key Research and Development Program of China (2016YFC0801800) and the National Nature Science Foundation of China $(51774291,51864045)$.

\section{Compliance with ethical standards}

Conflict of interest The authors certify that they have no affiliations with or involvement in any organization or entity with any financial interest or non-financial interest such as personal or professional relationships in the subject matter or materials discussed in this manuscript.

Ethical approval The authors certify that the experiments comply with the current laws of the country in which they were performed.

Open Access This article is licensed under a Creative Commons Attribution 4.0 International License, which permits use, sharing, adaptation, distribution and reproduction in any medium or format, as long as you give appropriate credit to the original author(s) and the source, provide a link to the Creative Commons licence, and indicate if changes were made. The images or other third party material in this article are included in the article's Creative Commons licence, unless indicated otherwise in a credit line to the material. If material is not included in the article's Creative Commons licence and your intended use is not permitted by statutory regulation or exceeds the permitted use, you will need to obtain permission directly from the copyright holder. To view a copy of this licence, visit http://creativecommons. org/licenses/by/4.0/.

\section{References}

Abbasi T, Abbasi SA (2007) Dust explosions-cases, causes, consequences, and control. J Hazard Mater 140:7e44

Addai EK, Gabel D, Krause U (2015) Lower explosion limit of hybrid mixtures of burnable gas and dust. J Loss Prev Process Ind 36:497-504

Addai EK, Gabel D, Krause U (2016) Experimental investigation on the minimum ignition temperature of hybrid mixtures of dusts and gases or solvents. J Hazard Mater 301:314-326

Ajrash MJ, Zanganeh J, Moghtaderi B (2016) Effects of ignition energy on fire and explosion characteristics of dilute hybrid fuel in ventilation air methane. J Loss Prev Process Ind 40:207-216

Ajrash MJ, Zanganeh J, Moghtaderi B (2017) The flame deflagration of hybrid methane coal dusts in a large-scale detonation tube (LSDT). Fuel 194:491-502 
Amyotte PR, Eckhoff RK (2010) Dust explosion causation, prevention and mitigation: an overview. J Chem Health Saf 17:15-28

Amyotte PR, Mintz KJ, Pegg MJ, Sun YH, Wilkie KI (1991) Laboratory investigation of the dust explosibility characteristics of three Nova Scotia coals. J Loss Prev Process Ind 4(2):102-109

Amyotte PR, Mintz KJ, Pegg MJ, Sun YH (1993) The ignitability of coal dust-air and methane-coal dust-air mixtures. Fuel 72(5):671-679

Boilard SP, Amyotte PR, Khan FI, Dastidar AG, Eckhoff RK (2013) Explosibility of micron- and nano-size titanium powders. J Loss Prev Process Ind 26(6):1646-1654

Bu Y, Li C, Amyotte P, Yuan W, Yuan C, Li G (2020) Moderation of $\mathrm{Al}$ dust explosions by micro- and nano-sized $\mathrm{Al}_{2} \mathrm{O}_{3}$ powder. J Hazard Mater 381:120968

Cashdollar KL (1996) Coal dust explosibility. J Loss Prev Process Ind 9(1):65-76

Denkevits A (2007) Explosibility of hydrogen-graphite dust hybrid mixtures. J Loss Prev Process Ind 20(4-6):698-707

Dufaud O, Perrin L, Traoré Mamadou (2008) Dust/vapour explosions: hybrid behaviours? J Loss Prev Process Ind 21(4):481-484

Eckhoff RK (2009) Understanding dust explosions. The role of powder science and technology. J Loss Prev Process Ind 22(1):105-116

Eckhoff RK (2012) Does the dust explosion risk increase when moving from $\mu \mathrm{m}$-particle powders to powders of nm-particles? J Loss Prev Process Ind 25(3):448-459

Fumagalli A, Derudi M, Rota R, Copelli S (2016) Estimation of the deflagration index $\mathrm{K}_{\mathrm{St}}$ for dust explosions: a review. J Loss Prev Process Ind 44:311-322

Gao C, Li H, Su D (2010) Explosion characteristics of coal dust in a sealed vessel. Explos Shock Waves 30(2):164-168

Gao W, Yu J, Zhang X, Li J, Wang B (2015) Characteristics of vented nano-polymethyl methacrylate dust explosions. Powder Technol 283:406-414

Garcia-Agreda A, Benedetto AD, Russo P, Salzano E, Sanchirico R (2011) Dust/gas mixtures explosion regimes. Powder Technol 205(1):81-86
Li Q, Wang K, Zheng Y, Ruan M, Mei X, Lin B (2016) Experimental research of particle size and size dispersity on the explosibility characteristics of coal dust. Powder Technol 292:290-297. https://doi.org/10.1016/j.powtec.2016.01.035

Liu Q, Bai C, Li X, Jiang L, Dai W (2010) Coal dust/air explosions in a large-scale tube. Fuel 89(2):329-335

Mittal M (2014) Explosion characteristics of micron- and nano-size magnesium powders. J Loss Prev Process Ind 27(1):55-64

Myers TJ (2008) Reducing aluminum dust explosion hazards: case study of dust inerting in an aluminum buffing operation. J Hazard Mater 159:72-80

Pilão R, Ramalho E, Pinho C (2006) Explosibility of cork dust in methane/air mixtures. J Loss Prev Process Ind 19(1):17-23

Proust C, Accorsi A, Dupont L (2007) Measuring the violence of dust explosions with the "20 L sphere" and with the standard "ISO $1 \mathrm{~m}^{3}$ vessel": systematic comparison and analysis of the discrepancies. J Loss Prev Process Ind 20(4):599-606

Rockwell SR, Rangwala AS (2013) Influence of coal dust on premixed turbulent methane-air flames. Combust Flame 160:635-640

Sanchirico R, Benedetto AD, Garcia-Agreda A, Russo P (2011) Study of the severity of hybrid mixture explosions and comparison to pure dust-air and vapour-air explosions. J Loss Prev Process Ind 24(5):648-655

Sapko MJ, Cashdollar KL, Green GM (2007) Coal dust particle size survey of US mines. J Loss Prev Process Ind 20(4-6):616-620

Turkevich LA, Dastidar AG (2015) Hachmeister Z, Lim M, Potential explosion hazard of carbonaceous nanoparticles: explosion parameters of selected materials. J Hazard Mater 295:97-103

Wu L, Jiang Z, Cheng W, Zuo X, Lv D, Yao Y (2011) Major accident analysis and prevention of coal mines in China from the year of 1949-2009. Min Sci Technol China 21(5):693-699

Zheng Y, Feng C, Jing G, Qian X, Li X, Liu Z, Huang PA (2009) statistical analysis of coal mine accidents caused by coal dust explosions in China. J Loss Prev Process Ind 22(4):528-532 